\title{
ANALYSIS OF CRITICAL THINKING IN CLASS 4 STUDENTS OF SDN 2 KUTOSARI IN THEMATIC LEARNING 2013 CURRICULUM
}

\section{Marchelina Dwi Saputri, Kartika Chrysti Suryandari}

Universitas Sebelas Maret

marchelinadwi08@gmail.com

\begin{tabular}{l} 
Article History \\
\hline accepted 30/09/2018 \\
approved 12/10/2018 \\
published 30/10/2018
\end{tabular}

Keywords critical thinking, thematic, learning

\begin{abstract}
Thematic learning in 2013 curriculum has competence time front that is ability thinking clear and critical. Student could said have ability critical thinking if they pass by 6 steps of Critical thinking. So this study was a purpose was to analyze critical thinking in class 4 students of SD N 2 Kutosari in thematic learning 2013 curriculum. This study used descriptive qualitative method. The research subjects were the fourth grade studenst of SD $N 2$ Kutosari. Data collection though observation, documentation and interview to the fourth grade student. Result research show ability critical thinking of class 4 student of SDN 2 Kutosari already exists, but students do not always think critically but only in limited learning. conducted students begin to be critical with $47,72 \%$ of students able to think critically. So the teacher lures students to think critically based on six step of critical thinking.
\end{abstract}

Social, Humanities, and Education Studies (SHEs): Conference Series https://jurnal.uns.ac.id/shes
p-ISSN 2620-9284

e-ISSN 2620-9292 


\section{PENDAHULUAN}

Pendidikan merupakan bagian terpenting dalam kehidupan manusia.Pendidikan tidak otomatis ada dengan sendirinya tetapi pendidikan adalah usaha dengan sadar dan terencanakan. Hal ini diatur dalam UU No. 20 Tahun 2003 yang menjelaskan pendidikan adalah usaha sadar dan terencana untuk mewujudkan suasana belajar dan proses pembelajaran agar peserta didik secara aktif mengembangkan potensi dirinya untuk memiliki kekuatan spiritual keagamaaan, pengendalian diri, kepribadian, kecerdasan, akhlak mulia, serta keterampilan yang diperlukan dirinya, masyarakat, bangsa, dan Negara." Potensi yang dimiliki oleh setiap siswa harus dikembangkan untuk mencapai tujuan dari pendidikan sehingga siswa dapat mencapai kehidupan yang lebih bermakna.Dalam pengembangkan potensi yang dimiliki oleh siswa pemerintah memberikan kurikulum 2013.

Kurikulum 2013 merupakan kurikulum yang diterapkan dari tahun 2013. Kurikulum 2013 mempunyai tujuan mempersiapkan manusia Indonesia agar memiliki kemampuan hidup sebagai pribadi dan warga negara yang beriman, produktif, kreatif, inovatif, dan afektif serta mampu berkontribusi pada kehidupan bermasyarakat, berbangsa, bernegara dan peradaban dunia. Dengan adanya kurikulum 2013 pemerintah telah menyiapkan generasi yang mampu berkontribusi terhadap kehidupannya maupun juga kehidupan orang lain serta kurikurikulum 2013 telah menyiapkan generasi yang siap menghadapi arus globalisasi dan siap menjadi generasi emas 2045 mendatang.

Generasi yang siap menghadapi arus globalisasi harus memiliki kompetensi masa depan. Kompetensi masa depan ini harus dipersiapkan sejak dini. Dengan hal ini pemerintah menyiapkan generasi emas 2045 melalui kurikulum 2013.Kompetensi yang disiapkan dalam menghadapi arus globalisasi pada kurikulum 2013 lebih menekankan kemampuan berkomunikasi, kemampuan berpikir jernih dan kritis, kemampuan mempertimbangkan segi moral.Berbeda dengan kurikulum 2006, kurikulum 2013 lebih menekankan pada kamampuan berpikir jernih dan kritis.Dengan adanya kurikulum 2013 siswa mempu berpikir kritis untuk menghadapi arus globalisasi masa mendatang. Berpikir kritis menurut Elaine (Rokayana dan Efendi, 2017) yaitu kemampuan untuk berpendapat dengan cara yang terorganisasi. Sedangkan menurut Desmita (Saragih, 2008) mengemukakakn berfikir kritis adalah pemahaman atau refleksi terhadap permasalahan secara mendalam, mempertahankan pikiran agar tetap terbuka bagi berbagai pendekatan dan persfektif yang berbeda.Ada 6 indikator berpikir kritis menurut Facione (Rokayana dan Efendi, 2017) yaitu interpretasi, inferensi, evaluasi, eksplanasi dan regulasi diri.

Berdasarkan beberapa pendapat ahli di atas, dapat diketahui bahwa berpikir kritis adalah pemikiran dalam memecahkan masalah secara terorganisir.Namun pada kenyataanya kemampuan berpikir kritis siswa masih rendah terbukti dari adanya artikel "Indonesia Darurat Berpikir kritis" yang ditulis oleh Jurnal Kebenaran Indonesia (2017).Berdasarkan fakta yang tersebut dapat diketahui bahwa tingkat berpikir kritis siswa masih rendah, terbukti dari banyaknya siswa yang belum mampu menarik kesimpulan dari kumpulan data, tidak dapat menangkap intisari pembelajaran.maka perlu adanya sikap berpikir kritis yang dimiliki oleh setiap sisa guna menghadapi generasi emas 2045 sejak dini. Akan tetapi, pada kenyaataanya masih banyak siswa yang belum dapat berpikir kritis untuk menyelesaikan permasalahan.

Peneliti tertarik melakukan penelitian di sekolah dasar karena tercapainya generasi emas 2045 dapat dilihat dari tingkat berpikir kritis siswa khususnya siswa SD karena pada tahun 2045 siswa SD memasuki usia produktif. Tercapainya generasi emas 2045 tergantung pada kemampuan berpikir kritis siswa SD pada saat ini.

Berdasarkan infomasi yang diperoleh, maka peneliti memutuskan untuk melakukan penelitian dengan judul "Analisis Kemampuan Berpikir Kritis Siswa Kelas IV SD N 2 Kutosari pada Pembelajaran Tematik Kurikulum 2013. 


\section{METODE}

Pada penelitian ini menggunakan penelitian deskriptif sederhana.Penggunaan penelitian deskriptif pada penelitian ini karena peneliti tidak melakukan tindakan terhadap subjek yang diteliti.Peneliti hanya melakukan pengamatan, wawancara, dan angket untuk mendapatkan data.

Penelitian ini dilaksanakan pada 12-15 September 2018 Di SD Negeri 2 Kutosari beralamat di Jalan Pahlawan 207, Kecamatan Kebumen, Kabupaten Kebumen, Jawa Tengah. Subjek penelitian ini adalah siswa kelas IV SD Negeri 2 Kutosari tahun ajaran 2018/2019, yang terdiri dari 33 siswa yang terdiri dari 22 laki-laki dan 11 perempuan. Data dalam penelitian ini berupa data kualitatif kemampuan berpikir kritis siswa yang terlihat dari kriteria sangat baik, baik, cukup, dan kurang baik.Pengambilan data pada penelitian ini menggunakan observasi dan wawancara.

Teknik analisis data pada penelitian ini adalah dengan mengunakan analisis deskriptif, data dan informasi yang didapatkan dideskripsikan secara kualitatif. Data yang dieproleh dijelaskan secara deskriptif.Berpikir kritis siswa diamati melalui observasi yang dilakukan oleh peneliti pada saat pembelajaran tematik.Selain itu, peneliti melakukan wawancara dengan siswa menggunakan pedoman wawancara.

Analisis yang dilakukan dalam penelitian ini dengan menghitung skor pada setiap aspek yang diamati yaitu

$$
\begin{array}{ll}
0-25 \% & \text { : Kurang baik } \\
26-50 \% & \text { : Cukup } \\
51-75 \% & \text { : Baik } \\
76-100 \% & \text { : Sangat baik }
\end{array}
$$

\section{HASIL DAN PEMBAHASAN}

Penelitian ini digunakan untuk menganalisis berpikir kritis siswa dalam pembelajaran tematik. Berpikir kritis menurut Elaine (Rokayana dan Efendi, 2017) yaitu kemampuan untuk berpendapat dengan cara yang terorganisasi. Ada 6 indikator berpikir kritis menurut Facione (Rokayana dan Efendi, 2017) yaitu interpretasi,

\begin{tabular}{|c|c|c|c|c|c|}
\hline \multirow{3}{*}{$\begin{array}{l}\text { Aspek } \\
\text { 1. Interpretasi }\end{array}$} & Indikator & 1 & 2 & 3 & 4 \\
\hline & $\begin{array}{l}\text { 1. Siswa dapat mengidentifikasi masalah } \\
\text { dari kejadian yang disajikan }\end{array}$ & $\sqrt{ }$ & & & \\
\hline & $\begin{array}{l}\text { 2. Siswa dapat membuat } 3 \text { pertanyaan } \\
\text { dari pengalaman/gambar kejadian } \\
\text { yang relevan }\end{array}$ & $\sqrt{ }$ & & & \\
\hline \multirow[t]{2}{*}{ 2. Analisis } & $\begin{array}{l}\text { 1. Siswa dapat menuliskan apa yang } \\
\text { harus dilakukan dalam menyelesaikan } \\
\text { masalah yang disajikan }\end{array}$ & & $\sqrt{ }$ & & \\
\hline & $\begin{array}{l}\text { 2. Siswa dapat menjawab } 3 \text { pertanyaan } \\
\text { dengan benar }\end{array}$ & & & $\sqrt{ }$ & \\
\hline \multirow[t]{2}{*}{ 3. Evaluasi } & $\begin{array}{l}\text { 1. Siswa dapat mengidentifikasi informasi } \\
\text { penting }\end{array}$ & & & $\sqrt{ }$ & \\
\hline & $\begin{array}{l}\text { 2. Siswa dapat melaporkan } \\
\text { fenomena/kejadian }\end{array}$ & & $\sqrt{ }$ & & \\
\hline 4. Inference & $\begin{array}{l}\text { 1. Siswa dapat merumuskan dugaan dan } \\
\text { hipotesis } \\
\text { 2. Siswa dapat membuat kesimpulan dari }\end{array}$ & $\sqrt{ }$ & $\sqrt{ }$ & & \\
\hline
\end{tabular}
inferensi, evaluasi, eksplanasi dan regulasi diri. Hasil observasi peneliti, berpikir kritis yang terdiri dari enam indikator sebagai berikut:

Tabel 1. Berpikir Kritis 
data/informasi yang diperoleh
5. Penjelasan 1. Siswa dapat menjelaskan hasil yang diperoleh
2. Siswa dapat menjelaskan kembali hasil dari presentasi siswa yang lainnya dengan

6. Regulasi Diri 1. Siswa secara sadar dan mempunyai motivasi untuk belajar.

Berdasarkan hasil observasi yang dilakukan oleh peneliti terhadap kemampuan berpikir kritis siswa kelas IV, maka data yang diperoleh:

1. Interpretasi

a. Siswa dapat mengidentifikasi masalah dari kejadian/gambar yang disajikan

Berdasarkan hasil observasi, siswa mengidentifikasi masalah dengan penjelasan dari guru sehingga siswa belum mampu sendiri untuk mengidentifikasi masalah yang telah disajikan.

b. Siswa mampu membuat 3 pertanyaan dari pengalaman/gambar/kejadian yang relevan Berdasarkan hasil observasi siswa belum mampu membuat 3 pertanyaan. Siswa mampu membuat 2 pertanyaan dari pengalaman/gambar/kejadian yang relevan.

2. Analisis

a. Siswa dapat menuliskan apa yang harus dilakukan dalam menyelesaikan masalah yang disajikan.

Berdasarkan hasil observasi, siswa dapat menuliskan apa yang harus dilakukan dalam menyelesaikan masalah yang disajikan tetapi masih sangat sederhana dengan bantuan guru.

b. Siswa dapat menjawab 3 pertanyaan dengan benar.

Berdasarkan hasil observasi, siswa sudah dapat menjawab 3 pertanyaan dengan benar.

3. Evaluasi

a. Siswa dapat mengidentifikasi informasi penting

Berdasarkan hasil observasi, siswa sudah dapat mengidentifikasi informasi penting berdasarkan kejadian/peristiwa yang relevan.

b. Siswa dapat melaporkan fenomena/kejadian

Berdasarkan hasil observasi, siswa sudah dapat melaporkan fenomena/kejadian tetapi belum runtut masih perlu bimbingan guru.

4. Interference
a. Siswa dapat merumuskan dugaan dan hipotesis

Berdasarkan hasil observasi, siswa belum mampu merumuskan dugaan dan hipotesis berdasarkan peristiwa yang terjadi.

b. Siswa dapat membuat kesimpulan dari data/informasi

Berdasarkan hasil observasi, siswa mampu membuat kesimpuan dari

5. Penjelasan data/informasi dengan bimbingan guru.

a. Siswa dapat menjelaskan hasil yang diperoleh

Berdasarkan hasil observasi, siswa sudah dapat menjelaskan hasil yang diperoleh tetapi kurang percaya diri.

b. Siswa dapat menjelaskan kembali hasil dari presentasi siswa yang lainnya dengan

Berdasarkan hasil observasi, siswa sudah dapat menjelaskan kembali hasil yang diperoleh tetapi kurang percaya diri. 


\section{Regulasi Diri}

a. Siswa secara sadar dan mempunyai motivasi untuk belajar.

Berdasarkan hasil observasi dan wawancara pada siswa kelas 4, siswa sudah memiliki motivasi untuk belajar tetapi pada pembelajaran tertentu.

Setelah melakukan observasi, data yang diperoleh dihitung dalam bentuk persentase menggunakan rumus analisis deskriptif sederhana yaitu:

$$
\begin{aligned}
\text { Presentase } & =\frac{\text { skor } \text { keseluru han yang diperole } h}{\text { skor maksimal }} \times 100 \% \\
& =\frac{21}{44} \times 100 \% \\
& =\ldots . .100 \% \\
& =47,72 \%
\end{aligned}
$$

Jadi, kemampuan berpikir kritis siswa dalam pembelajaran tematik kurikulum 2013 memiiki kriteria "cukup" dengan persentase 47,72\%.

Aspek yang ditekankan pada penelitian ini adalah interpretasi, analisis, Evaluasi, Interence, penjelasan dan regulasi diri. Berikut ini merupakan uraiannya:

1. Interpretasi

Berdasarkan data hasil observasi, kemampuan siswa dalam mengidentifikasi masalah kurang harus dengan dipancing oleh guru.Siswa sudah mampu membuat 2 pertanyaan dari pengalaman/gambar yang disajikan oleh guru.

2. Analisis

Berdasarkan data hasil observasi, siswa dalam menuliskan apa yang harus dilakukan dalam menyelesaikan masalah masih kurang runtut. Siswa lebih cenderung langsung melakukan daripada menulis apa yang harus dilakukan dalam menyelesaikan masalah. Sehingga siswa menulis dengan sederhana.Siswa kelas 4 sudah mampu menjawab 3 pertanyaan dengan benar.Tetapi jawabannya belum kompleks.

3. Evaluasi

Berdasarkan data hasil observasi, siswa dalam evaluasi meliputi mengidentifikasi informasi penting sudah mampu memilih informasi penting dan informasi tidak penting dengan bimbingan guru.Misalnya dalam bacaan siswa tidak membutuhkan waktu yang lama untuk mencari informasi penting dalam bacaan tersebut. Sedangkan kemampuan siswa dalam melaporkan fenomena/kejadian masih kurang meskipun siswa sudah bisa, tetapi siswa kurang runtut dan lengkap dalam melaporkan peristiwa/kejadiannya

4. Interfence

Berdasarkan data hasil observasi, siswa dalam kemampuan inference siswa cenderung belum mampu hal ini dikarenakan saat siswa membuat/merumuskan dugaan siswa cenderung suka berpindah-pindah jawaban.Sedangkan saat membuat kesimpulan siswa harus diberi rangsangan oleh guru terlebih dahulu.

5. Regulasi Diri

Berdasarkan data hasil observasi dan wawancara pada siswa kelas 4.Sebagian besar mereka belajar pada malam hari.Dengan dorongan orang tua.Siswa lebih suka belajar pelajaran yang mereka sukai.Dengan fasilitas buku yang ada menjadikan siswa lebih termotivasi dalam belajar.

\section{SIMPULAN}

Berdasarkan data diperoleh peneliti, maka dapat disimpulkan bahwa kemampuan berpikir kritis siswa kelas IV SD Negeri 2 Kutosari termasuk dalam kategori cukup dengan persentase $47,72 \%$. Hasil tersebut didapat dari observasi dan wawancara yang menunjukkan siswa mulai terlihat keterampilan interpretasi, mulai muncul 
keterampilan analisis, Sudah terlihat jelas keterampilan Evaluasi, mulai muncul keterampilan inference, Sudah mulai memiliki Regulasi Diri.Maka dari itu untuk mencapai generasi emas 2045 perlu adanya peningkatan kemampuan berpikir kritis siswa.

\section{DAFTAR PUSTAKA}

Rokayana dan Efendi.(2017). Analisis Keterampilan Berpikir Kritis Siswa SMP Pada Mata Pelajaran IPA Ditinjau Dari Gaya Belajar Visual. Science Education Jurnal Vol I No. 2

Saragih, S. (2008).Mengembangkan Keterampilan Berpikir Matematika. Jogjakarta: UNY

UU No 20 tahun 2003 Tentang Sistem Pendidikan Nasional.

Wibowo.(2017). Indonesia Darurat Berpikir Kritis. Jurnal Kebenaran. Diunduh dari https://jurnalkebenaran.com/sosial/indonesia-darurat-berpikir-kritis/. 